\title{
A soluble form of the urokinase plasminogen activator receptor (suPAR) can bind to hematopoietic cells
}

\author{
Ikuko F. Mizukami and Robert F. Todd, III \\ Division of Hematology/Oncology, Department of Internal M edicine, \\ and the University of Michigan Comprehensive Cancer Center, Ann Arbor
}

Abstract: The receptor for urokinase plasminogen activator (UPAR; CD87) is a 50- to 65-kDa glycosylphosphatidylinositol (GPI)-anchored glycoprotein expressed by leukocytes and tumor cells where it facilitates uPA-dependent, plasmin-mediated pericellular proteolysis during cellular invasion. B ecause UPAR is inducibly shed into culture supernatants and human body fluids, we tested the hypothesis that soluble UPAR (suPAR) can bind to the plasma membrane of hematopoietic cells where it might modulate their invasive phenotype. As measured by flow cytometry, recombinant biotinylated-suPAR (B-suPAR) bound in a specific fashion to THP-1 leukemia cells and blood PMNs and monocytes (but not to lymphocytes). B-suPAR also demonstrated specific binding to a variety of leukemic lines, including cells that are positive or negative for membrane uPAR expression. Binding of B-suPAR to THP-1 cells was enhanced four- to sevenfold by 24-h exposure of cells to PMA or by co-incubation with uPA ligand (but not its isolated catalytic and binding fragments). Conversely, binding of B-suPAR to PMNs was unaffected by brief exposure to $f M L P$, and was inhibited by coincubation with UPA. B-suPAR binding to PMAdifferentiated THP-1 cells in the presence of UPA was further enhanced by acid washing (removing endogenous UPA) but was partially inhibited by treatment of cells with trypsin. Pretreatment of PMA-differentiated THP-1 cells and unstimulated PMNs with soluble sugars, calcium chelators, and antibodies specific for integrins or extracellular matrix proteins failed to consistently block the binding of B -suPAR. Whereas the binding of suPAR did not measurably affect cell-associated plasmin activation, suPAR did competitively inhibit the binding of exogenous uPA to membrane-associated UPAR. These observations support the hypothesis that suPAR can bind specifically to trypsin-sensitive receptors expressed by certain normal and neoplastic hematopoietic cells where its binding is variably influenced by uPA ligand. J. Leukoc. Biol. 64: 203-213; 1998.

Key Words: soluble receptor $\cdot$ binding

\section{INTRODUCTION}

The receptor for urokinase plasminogen activator (UPAR; CD87) is a 50- to 65-kDa glycosylphosphatidylinositol (GPI)anchored glycoprotein that is variably expressed by many hematopoi etic cells, including mononuclear phagocytes, neutrophils (PMNs), T lymphocytes, and eosinophils, as well as by non-hematopoietic cells including endothelial cells, fibroblasts, smooth muscle cells, keratinocytes, hepatocytes, and placental trophoblasts [reviewed in refs. 1 and 2]. The density of plasma membrane UPAR expression on these cells is up-regulated by a variety of activating factors, including many inflammatory cytokines and bacterial products [e.g., lipopolysaccharide (LPS) and muramyl dipeptide] [3-7]. In addition to its expression by normal cells, UPAR is found on the surface of both hematopoietic and non-hematopoietic tumor cells. Membrane UPA R is localized to the leading edge (lamellipodium) of migrating inflammatory leukocytes and tumor cells where it facilitates pericellular proteolysis in the path of invasion by focusing the enzymatic activity of its bound ligand UPA to adjacent plasminogen receptors $[1,2]$. In addition to its role in fostering the invasion of inflammatory leukocytes and tumor cells, UPAR has been implicated in several other UPAdependent cellular processes including leukocyte differentiation [8], tumor cell mitogenesis [9], vitronectin binding [10], and neutrophil priming [11]. UPAR, independent of UPA, also modulates several integrin functions including PM N/monocyte chemotaxis $[12,13]$ and cellular adhesion to substrates [14, 15]. The regulation of integrin adhesive function may be one manifestation of a symbiotic relationship between UPAR and several members of the $\beta_{1}, \beta_{2}$, and $\beta_{3}$ integrin families in which

Abbreviations: ATF, amino-terminal fragment (of UPA); ELISA, enzymelinked immunosorbent assay; FITC, fluorescein isothiocyanate; $F$ L $P$, formylmethionyl-leucyl-phenylalanine; GPI, glycosyl phosphatidylinositol; H MW, high molecular weight; LMW, low molecular weight; LPS, lipopolysaccharide; $\mathrm{MA} b$, monoclonal antibody; PI-PLC, phosphatidylinositol-specific phospholipase C; PMA, phorbol myristate acetate; PMNs, neutrophils; SA-PE, streptavidinphycoerythrin; SDS-PAGE, sodium dodecylsulfate-polyacrylamide gel electrophoresis; TNF- $\alpha$, tumor necrosis factor $\alpha$; UPA, urokinase plasminogen activator; UPAR, receptor for UPA; sUPAR, soluble UPAR; B-sUPAR, biotinylated suPAR; PBS, phosphate-buffered saline; HBSS, Hanks' balanced salt solution.

Correspondence: Robert F. Todd, III, M.D., Ph.D., Division of Hematology/ Oncology, 7216 CCGC, University of Michigan Medical Center, 1500 E. Medical Center Drive, Ann A rbor, MI 48109-0948.

Received December 11, 1997; revised A pril 14, 1998; accepted A pril 16, 1998 
integrins, as transmembrane molecules, serve as signaling partners for UPAR (which has no structural link to the cytoplasm) [reviewed in refs. 16, 17]. In support of this notion, we and others have reported a reversible physical linkage between UPAR and integrin glycoproteins in the plasma membrane of neutrophils, monocytes, and epithelial tumor cells $[15,18-23]$.

UPAR, like several other GPI-anchored glycoproteins [24], is shed from the surface of uPA R -expressing cells either constitutively or in response to certain soluble stimuli. We have recently reported that exposure of U-937 monocytic leukemia cells to tumor necrosis factor $\alpha$ (TNF- $\alpha$ ) is a stimulus for both UPAR biosynthesis and shedding [25]. The physiological relevance of this in vitro phenomenon is suggested by our detection of a soluble form of UPAR (suPAR) in the plasma and other body fluids of normal individuals and patients with inflammatory conditions [26]. Normal human plasma contains low levels of suPAR ( $3 \pm 3 \mathrm{ng} / \mathrm{mL}$ ), whereas the plasma of patients with clinical sepsis syndrome contains higher levels of suPAR $(30 \pm 11 \mathrm{ng} / \mathrm{mL})$ [26]. Moreover, the extravascular fluids (pleural, pericardial, and peritoneal) of 84 individuals with acute and chronic inflammatory conditions contained sUPA R with a wide concentration range of 2-253 $\mathrm{ng} / \mathrm{mL}$ [26]. suPA R contained within the plasma or body fluids of patients with inflammatory conditions was functionally active as evidenced by its ability to bind exogenous uPA [26]. Similar findings have been reported by R onne [27], Pappot [28], and Ploug [29] and their co-workers, who detected suPAR in the sera of normal individuals and, in higher concentrations, in the sera of patients with lung cancer and paroxysmal nocturnal hemoglobinuria. Similarly, Pedersen et al. [30] reported the presence of high concentrations of suPA R in the ascites fluid of patients with ovarian carcinoma.

The phenomenon of UPAR shedding has led to the question of what function, if any, is subserved by this molecule. The potential physiological significance of UPAR is suggested by the capacity of recombinant sUPAR to inhibit the proliferation and invasion of tumor cells in vitro [31, 32], to block binding of pro-uPA to the $\alpha_{2}$ macroglobulin receptor [33], and to reconstitute UPAR-dependent integrin-mediated adhesion [14]. The first two of these activities is consistent with a scavenger function, whereby suPAR competes with membrane UPAR for UPA binding. However, the latter activity would seem to require suPAR binding to the cell surface where it functions to modulate integrin function. The capacity of soluble forms of CD14 and CD16b (also GPI-anchored glycoproteins) to bind to cell membranes, either emparting or modifying cellular function $[34,35]$, is precedent for this concept. The focus of this study was to test the hypothesis that suPAR can indeed bind to the plasma membrane of hematopoietic cells where it might modulate the invasive phenotype. We found that recombinant, biotinylated-suPAR bound in a specific fashion to THP-1 leukemia cells and to blood PMNs and monocytes. Specific binding to THP-1 cells was enhanced by PMA-induced differentiation and by co-incubation with UPA; binding to PMNs was unaffected by activating stimuli or UPA ligand. suPA R binding was inhibited by pretreatment of THP-1 cells with trypsin, but its binding to THP-1 cells and PMNS was not consistently affected by pretreatment with anti-integrin monoclonal antibodies ( $\mathrm{mA}$ b) or by sugars that inhibit linkage between UPA R and integrins on the cell membrane.

\section{MATERIALS AND METHODS}

\section{Monoclonal antibodies and reagents}

Anti-CD11a mAb TS1/22 [36] and anti-CD18 mAb TS1/18 [36] were obtained from the ATTC (Rockville, MD) and used in the form of ascites; IgG anti-CD11b $\mathrm{mAb} 44$ [37], anti-CD87 mA b 3B10 [38] and anti-CD11C mA b 2E 1 [39] [the hybridoma was a gift of Dr. Timothy Springer (Harvard University)] were purified from murine ascites [38]; anti-CD11b MA b V IM 12 [40] was a gift of Dr. Walter Knapp, University of Vienna and used in the form of ascites; rabbit polyclonal antibodies specific for vitronectin (antiserum), fibronectin (antiserum), and thrombospondin ( $(\mathrm{gG})$ were purchased from Calbiochem (San Diego, CA ). Control murine myeloma proteins I gG I, I gG2a, and I gG2b were purchased from Cappel (West Chester, PA). Normal rabbit IgG was purified from pooled rabbit sera. PMA, FMLP, orosomucoid, $\alpha$-methyl-D-mannopyranoside, $\mathrm{N}$-acetylD-glucosamine (NADG), sucrose, zymosan, EGTA, and EDTA were purchased from Sigma Chemical Corp. (St. Louis, MO). Trypsin and DNAse I were purchased from GIBCO-BRL (Gaithersburg, MD) and Boehringer Mannheim (Indianapolis, IN), respectively. High molecular weight (HMW) UPA, Iow molecular weight (LMW) UPA, and the amino-terminal fragment (ATF) of UPA; Spectrozyme PL; and anti-uPA antibodies were the gifts of Dr. Richard Hart, A merican Diagnostica Inc. (Greenwich, CT). Streptavidin-PE (SA-PE), FITCconjugated goat anti-mouse, and anti-rabbit IgG were purchased from MolecuIar Probes (Eugene, OR), Calbiochem, and Pierce (R ockford, IL), respectively. PI-PLC was a gift of Dr. Martin Low (Columbia University).

\section{Production of recombinant suPAR}

A stable line (a gift of Dr. R obert Cohen, Genentech) secreting truncated UPA R was obtained by transfection of MM 293 cells as previously described [41]. suPAR was purified from concentrated, serum-free conditioned medium by affinity chromatography on ATF-Sepharose after acid-glycine elution. Purity of suPAR was confirmed by sodium dodecyl sulfate-polyacrylamide gel electrophoresis (SDS-PAGE), which showed a single broad band of material at approximately 50-55 kDa. Its immunological and functional activities were documented by enzyme-linked immunosorbent assay (ELISA) [26]. Biotinylation was performed by incubating recombinant suPAR, $1 \mathrm{mg} / \mathrm{mL}$, and sulfo-NHS-LSbiotin (Pierce; at a molar ratio of $1: 25$, respectively) in $0.1 \mathrm{M}$ sodium bicarbonate, $\mathrm{pH} 8.3$, on ice for $2 \mathrm{~h}$. The resulting $\mathrm{B}$-suPAR was dialyzed against phosphate-buffered saline (PBS) [42].

\section{Cells}

THP-1, U-937, K G-1, K G-1a, K562, and HL-60 human myeloid leukemic cell lines (originally obtained from ATCC) were grown in RPMI 1640 medium (BioW hittaker, Walkersville, MD) supplemented with $2 \mathrm{mM}$ L-glutamine, 10 $\mu \mathrm{g} / \mathrm{mL}$ penicillin-streptomycin, and $10 \%$ calf serum (HyCLone Lab., Logan, UT). In certain experiments, these cells $\left(\sim 0.5 \times 10^{6} \mathrm{~mL}\right)$ were cultured for 24 $\mathrm{h}$ at $37^{\circ} \mathrm{C}$ in the same medium containing $10 \mathrm{nM} \mathrm{PMA}$. A fter exposure to PMA, these THP-1 cells displayed an 11- and 7-fold increase in their expression of CD11b and CD87, respectively (data not shown). In other experiments, PMA-differentiated THP-1 cells were subsequently subjected to the following conditions. A cid wash: cells were incubated for $3 \mathrm{~min}$ at $4^{\circ} \mathrm{C}$ in $50 \mathrm{mM}$ glycine and $0.1 \mathrm{M} \mathrm{NaCl}, \mathrm{pH} 3.0$, quenched with $0.5 \mathrm{M} \mathrm{HEPES}$ and $0.1 \mathrm{M} \mathrm{NaCl}, \mathrm{pH} 7.5$, containing bovine serum albumin (BSA; $1 \mathrm{mg} / \mathrm{mL}$ ), followed by washing in PBS. Trypsin treatment: cells were incubated for $30 \mathrm{~min}$ at $37^{\circ} \mathrm{C}$ in $\mathrm{H}$ anks' balanced salt solution (HBSS) containing $0.25 \%$ trypsin along with $100 \mu \mathrm{g} / \mathrm{mL}$ DNA se I followed by the addition of calf serum to $20 \%$ and washing. PI-PLC treatment: cells were incubated for $30 \mathrm{~min}$ at $37^{\circ} \mathrm{C}$ in PBS containing $0.5 \mathrm{IU} / \mathrm{mL}$ PI-PLC followed by washing. After informed consent, human peripheral blood was collected from normal volunteer donors into heparinized syringes. PM Ns were isolated after Ficoll-Hypaque density gradient centrifugation as previously described [13]. In other experiments, unfractionated buffy coat leukocytes were collected after Dextran sedimentation followed by lysis of contaminating 
erythrocytes as previously described [43]. For some experiments, isolated PM N s or buffy coat leukocytes were incubated $\left(1 \times 10^{7}\right.$ cells $\left./ \mathrm{mL}\right)$ in Dulbecco's PBS containing $1 \mu \mathrm{M} \mathrm{fMLP}$ for $10 \mathrm{~min}$ at $37^{\circ} \mathrm{C}$, followed by washing in cold buffer.

\section{Flow cytometric analysis}

Based on a soluble receptor binding assay reported by Galon et al. [35], single cell suspensions ( 2.5 to $5 \times 10^{5}$ cells in $50 \mu \mathrm{L}$ ) were incubated for varying times (generally $60 \mathrm{~min}$ ) at $25^{\circ} \mathrm{C}$ with B-suPAR $(0.2-0.5 \mu \mathrm{M})$. Cells were then washed and incubated for $30 \mathrm{~min}$ at $25^{\circ} \mathrm{C}$ with SA-PE $(1 \mu \mathrm{g} / 50 \mu \mathrm{L})$. A fter washing, 5,000 viable cells were analyzed on a Coulter Elite or XL flow cytometry system (Coulter Electronics, Hialeah, FL). In the case of buffy coat specimens, lymphocytes, PMNs, and monocytes were gated separately by forward and side scatter. Competition experiments were performed by preincubating 2.5 to $5 \times 10^{5}$ cells for $60 \mathrm{~min}$ at $25^{\circ} \mathrm{C}$ with varying concentrations of un-biotinylated SUPAR; control proteins such as orosomucoid, murine monoclonal antibodies (purified IgG or ascites), polyclonal antisera; sugars $(0.15 \mathrm{M})$; zymosan $(1 \mathrm{mg} / \mathrm{mL})$; and EDTA or EGTA $(10 \mathrm{mM})$ before the addition of 0.2-0.5 $\mu \mathrm{M}$ B-suPAR as described above. In certain experiments, uPA ligand (either HMW, LMW, or the ATF of UPA) was added ( 0.1-20 $\mu \mathrm{M})$ to the cells either simultaneously with the addition of B-suPAR or pre-incubated with B-suPAR for $60 \mathrm{~min}$ at $25^{\circ} \mathrm{C}$ before the addition of the mixture to the cell suspension.

Indirect immunofluorescent analysis of cell surface antigen expression was performed as previously published, in which $5 \times 10^{5}$ cells suspended in PBS containing $1 \mathrm{mg} / \mathrm{mL}$ human IgG was incubated for $30 \mathrm{~min}$ at $4^{\circ} \mathrm{C}$ with the indicated monoclonal and polyclonal reagents, washed, and then incubated for an additional $30 \mathrm{~min}$ at $4^{\circ} \mathrm{C}$ in PBS containing FITC-conjugated goat anti-rabbit or anti-mouse IgG [38]. After final washing, cells were fixed in $1 \%$ formaldehyde.

\section{Cell-associated plasminogen activation assay [44]}

suPAR and $0.05 \mu \mathrm{M}$ UPA were incubated together at $25^{\circ} \mathrm{C}$ for $10 \mathrm{~min}$ and then added to $2 \times 10^{5}$ PMA-differentiated and acid-washed THP-1 cells. After incubation for $60 \mathrm{~min}$ at $25^{\circ} \mathrm{C}$ followed by extensive washing $(5 \times), 0.5 \times 10^{5}$ cells in triplicate were assayed for plasminogen activation by incubating in 100 $\mu \mathrm{L}$ of $0.5 \mathrm{mM}$ Spectrozyme PL with $1 \mu \mathrm{g}$ plasminogen for $2 \mathrm{~h}$ at $37^{\circ} \mathrm{C}$. The color developed was read at $405-490 \mathrm{~nm}$ with a microplate reader.

\section{Statistics}

Comparisons between group means were performed using Student's t test, where a $P$ value $\leq 0.05$ was considered statistically significant.

\section{RESULTS}

Immunoaffinity-purified recombinant suPA R was biotinylated (B-suPAR) and tested for its capacity to bind to the human monocytic leukemic cell line, TH P-1 and to isolated peripheral blood PMNs. As shown in Figure 1, when these cells were incubated for $60 \mathrm{~min}$ at $25^{\circ} \mathrm{C}$ in buffer containing the indicated concentrations of $B$-sUPAR, the amount of suPA R bound varied according to the input concentration. Saturation of B-suPAR binding was approached or reached at concentrations $>20 \mu \mathrm{M}$ (data not shown). When THP-1 cells were pre-exposed to the differentiating agent PMA $(10 \mathrm{nM})$ for $24 \mathrm{~h}$, the amount of $B$-suPAR bound increased (two- to threefold, $n=3$ experiments). Pre-exposure of isolated PMNs to fMLP $(1 \mu \mathrm{M})$ for 10 $\min$ at $37^{\circ} \mathrm{C}$ (under conditions that trigger granule exocytosis and increase the membrane expression of several granuleassociated receptors) had no consistent impact on suPAR binding, comparing the results of multiple donors. SUPAR binding at $37^{\circ} \mathrm{C}$ was comparable to that observed at $25^{\circ} \mathrm{C}$; binding at $4^{\circ} \mathrm{C}$ was consistently less (data not shown). The kinetics of $B$-suPA R binding to THP-1 cells and PMN $s$ at $25^{\circ} \mathrm{C}$ is shown in Figure 2. A major proportion of B-suPA R binding
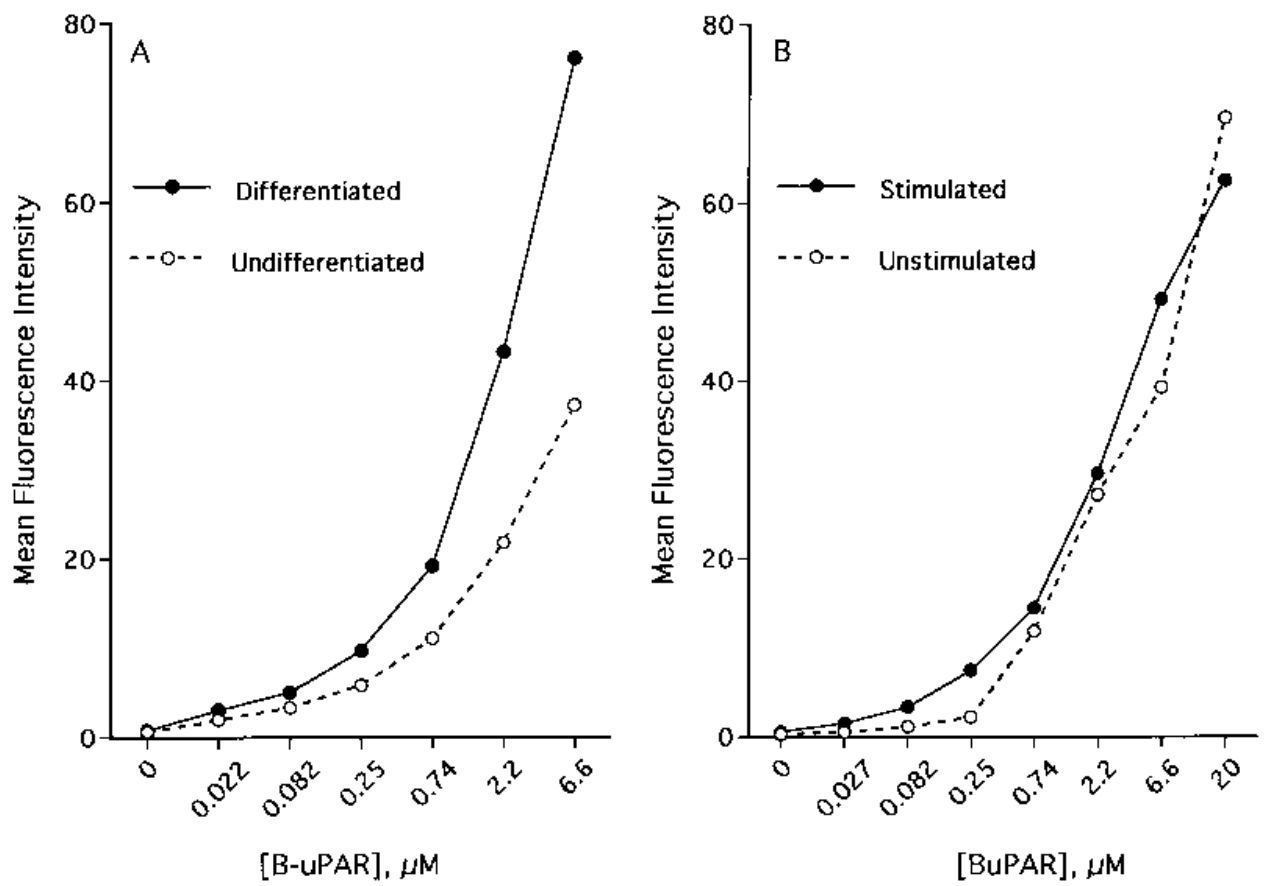

Fig. 1. Titration of B-sUPAR binding to THP-1 cells and to isolated peripheral blood PMNs. THP-1 cells (A) (either undifferentiated or differentiated by exposure to $10 \mathrm{nM}$ PMA for $24 \mathrm{~h}$ at $37^{\circ} \mathrm{C}$ ) and isolated peripheral blood PMNs (B) (either unstimulated or stimulated by exposure to $1 \mu \mathrm{M}$ fMLP for $10 \mathrm{~min}$ at $37^{\circ} \mathrm{C}$ ) were incubated for $60 \mathrm{~min}$ at $25^{\circ} \mathrm{C}$ with the indicated amounts of B-suPA R. A fter washing and incubation with SA-PE for 30 min at $25^{\circ} \mathrm{C}$, cells were analyzed for bound B-suPAR as quantitated by their mean fluorescence intensity (in arbitrary units). Similar results were seen in three other experiments. 

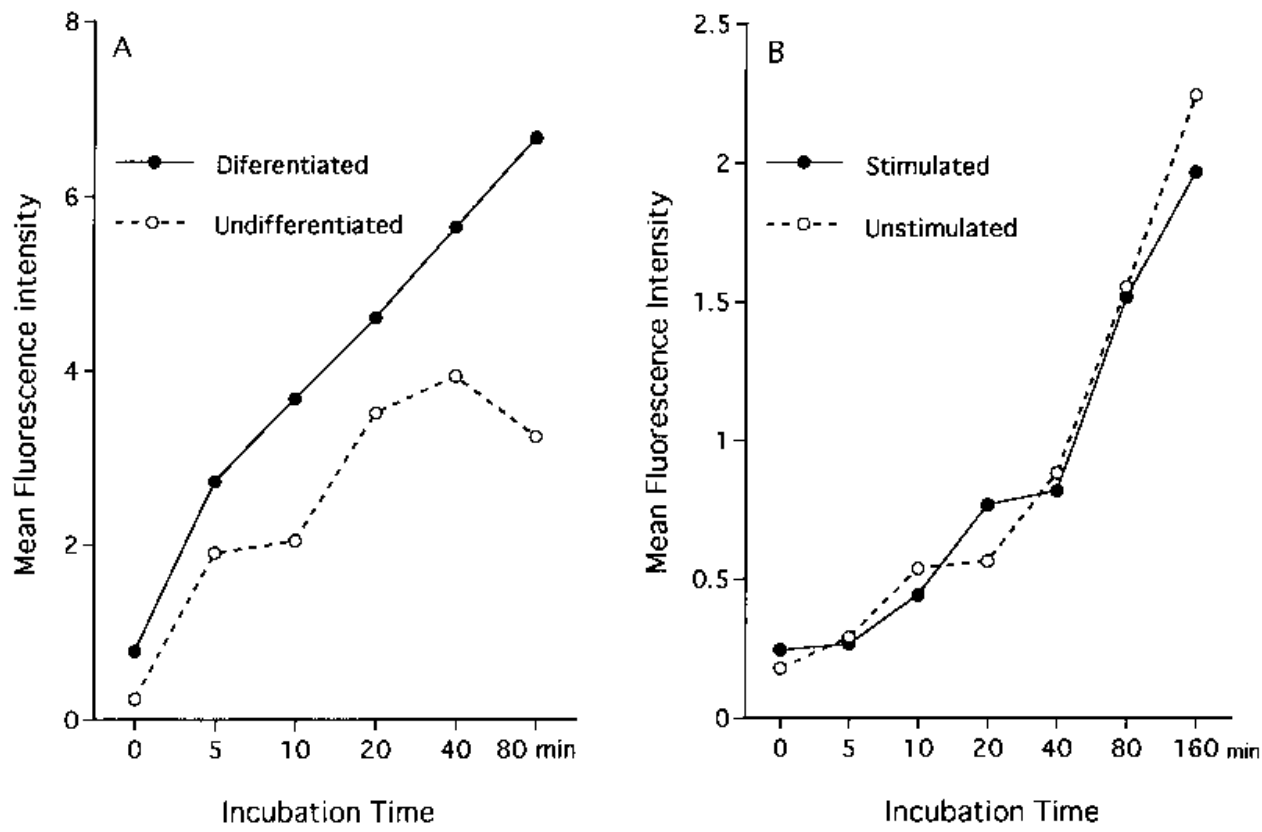

Fig. 2. Kinetics of suPAR binding to THP-1 cells and to isolated peripheral blood PMNs. THP-1 (A) cells and isolated peripheral blood PMNs (B) (either unstimulated or pretreated with PMA or FMLP, respectively, as indicated in Fig. 1) were incubated at $25^{\circ} \mathrm{C}$ for the indicated times with a fixed quantity of B-suPAR $\left(0.2 \mu \mathrm{M}\right.$ for TH P-1 cells; $0.5 \mu \mathrm{M}$ for PM N s). A fter washing and incubation with SA-PE for $30 \mathrm{~min}$ at $25^{\circ} \mathrm{C}$, the cells were analyzed for bound B-suPAR as indicated by their mean fluorescence intensity (arbitrary units). Similar results were seen in another experiment.

is specific as reflected by the competitive inhibition of saturating quantities of unlabeled suPAR [Fig. 3; also found to occur with $\mathrm{B}$-suPA R binding at $4^{\circ} \mathrm{C}$ (data not shown)].

To determine the impact of uPA ligand on the binding of B-suPAR, we exposed THP-1 or PMN target cells to a fixed concentration of $B$-suPA $R$ admixed with varying concentrations of intact (H M W) UPA. The B-suPA R and UPA were either added simultaneously to the target cells or were premixed for $1 \mathrm{~h}$ at $25^{\circ} \mathrm{C}$ (to allow complex formation). As shown in Figure 4, the addition of UPA enhanced the binding of B-suPAR to PMAstimulated THP-1 cells with optimal binding occurring at a $B$-suPAR : UPA ratio of $\sim 1: 30$. Pre-incubation of $B$-suPA $R$ with UPA resulted in less binding compared with simultaneous addition of reactants. In contrast, uPA had very little measur-
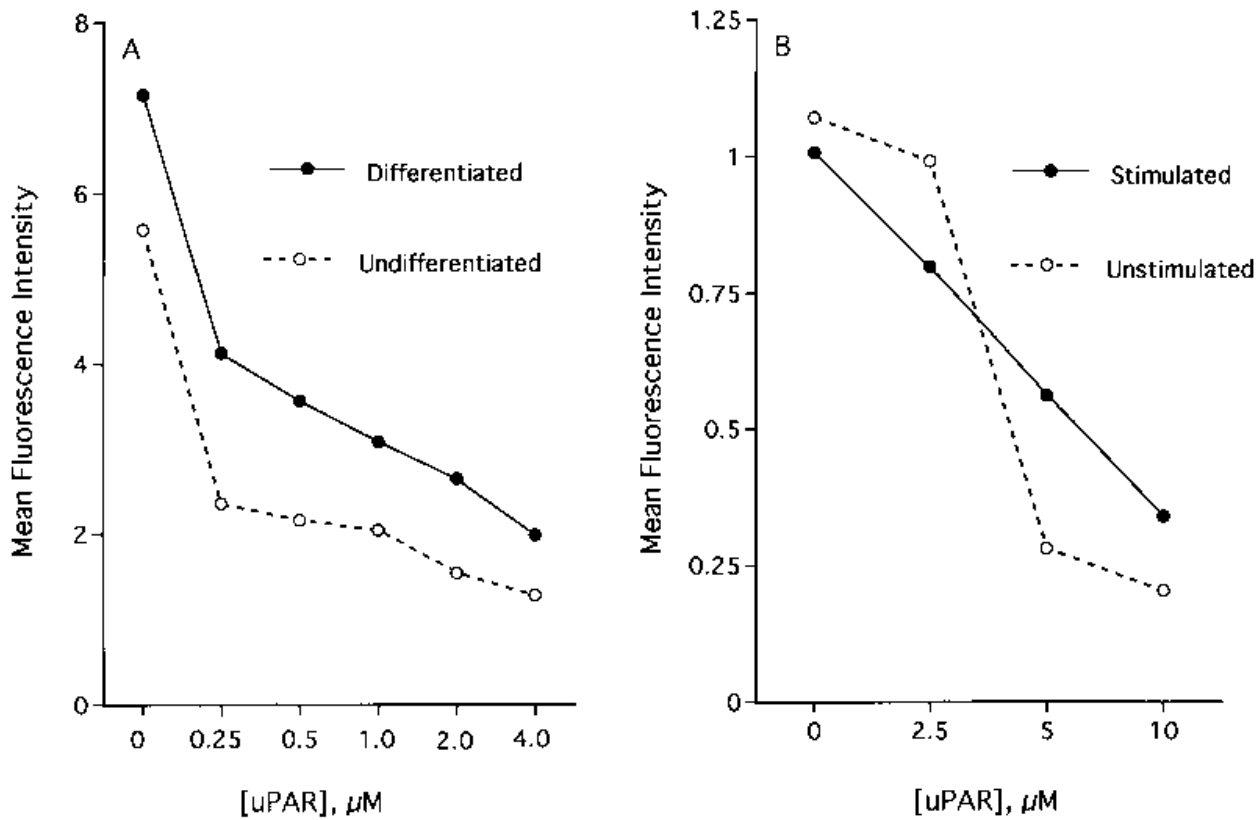

Fig. 3. Specificity of suPAR binding to THP-1 cells and to isolated peripheral blood PMNs. THP-1 cells (A) and isolated peripheral blood PMNS (B) (either unstimulated or pretreated with PMA or fMLP, respectively, as indicated in Fig. 1) were pre-incubated for 60 min at $25^{\circ} \mathrm{C}$ with the indicated amounts of unbiotinylated suPAR and then, without washing, incubated for an additional $60 \mathrm{~min}$ at $25^{\circ} \mathrm{C}$ with a fixed amount of B-suPAR $(0.2 \mu \mathrm{M}$ for THP-1 cells; $0.5 \mu \mathrm{M}$ for PMNs). After washing and incubation with SA-PE for $30 \mathrm{~min}$ at $25^{\circ} \mathrm{C}$ cells were analyzed for bound B-suPAR as indicated by their mean fluorescence intensity (arbitrary units). Similar results were seen in three other experiments. 


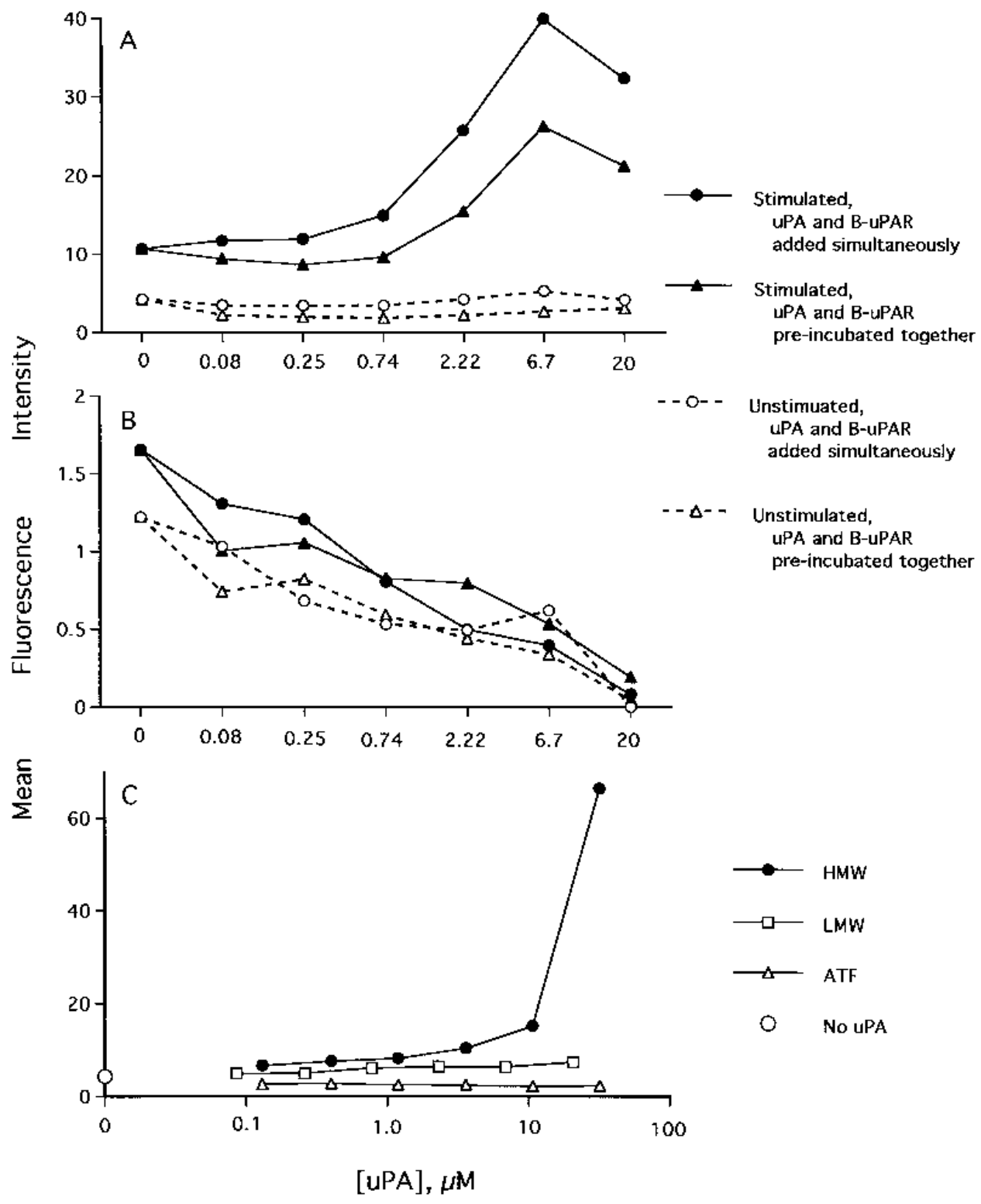

Fig. 4. Effect of uPA on the binding of $B$-suPAR to THP-1 cells and isolated peripheral blood PMNs. THP-1 cells (A) and isolated peripheral blood PMNs (B) (either unstimulated or pretreated with PMA or fMLP, respectively, as indicated in Fig. 1) were incubated for 60 min at $25^{\circ} \mathrm{C}$ with a mixture of B-suPAR (0.2 $\mu$ M for TH P-1 cells; $0.5 \mu \mathrm{M}$ for PM Ns) plus the indicated amounts of HMW uPA, which were either added simultaneously to the cell suspensions or pre-incubated together for 60 min at $37^{\circ} \mathrm{C}$ before their addition to the cells. A fter washing and incubation with SA-PE for $30 \mathrm{~min}$ at $25^{\circ} \mathrm{C}$, the cells were analyzed for bound B-suPAR as indicated by their mean fluorescence intensity (arbitrary units). In panel C, H M W, LMW, or ATF of uPA were added simultaneously to PMA-differentiated TH P-1 cells. Similar results were seen in three other experiments for $A$ and $B$, and one other experiment for $C$.

able impact on the binding of B-suPAR to unstimulated THP-1 cells and produced an inhibition of B-suPAR binding to PMNS (either unstimulated or unstimulated by fMLP). To determine whether intact HMW-uPA is required to produce maximum levels of B-suPAR binding to PMA-differentiated THP-1 cells, the effect of H MW uPA was compared to that of its N-(ATF) and carboxyl-terminal (LMW) domain fragments (possessing independent receptor binding and catalytic activities, respectively). As shown in Figure $4 C$, only intact HMW UPA was able to enhance the binding of B-suPAR to PMA-differentiated THP-1 cells.

Because exogenous HMW UPA influenced the binding of B-suPAR to THP-1 cells, we sought to determine the effect of removing endogenous UPA from membrane-associated UPAR compared with other modifications of the target cell surface, including treatment with phosphatidyl inositol-specific phospholipase $C$ (PI-PLC) or trypsin (to deplete the membrane of $\mathrm{GPI}$-anchored and trypsin-sensitive proteins, respectively). As shown in Figure 5, acid washing of PMA-differentiated TH P-1 cells under conditions sufficient to remove greater than $90 \%$ of endogenously bound uPA (Fig. 5B) produced an increase in $B$-suPAR binding, which was observed in the absence or presence of exogenous UPA (Fig. 5A). Treatment of cells with PI-PLC (which removed $70 \%$ of endogenous uPA and approximately $40 \%$ of membrane-associated UPAR) had minimal impact on suPAR binding. Trypsin treatment (sufficient to deplete THP-1 cells of nearly all membrane-associated UPA and $U P A R$ ) produced a partial inhibition of specific B-suPA $R$ 

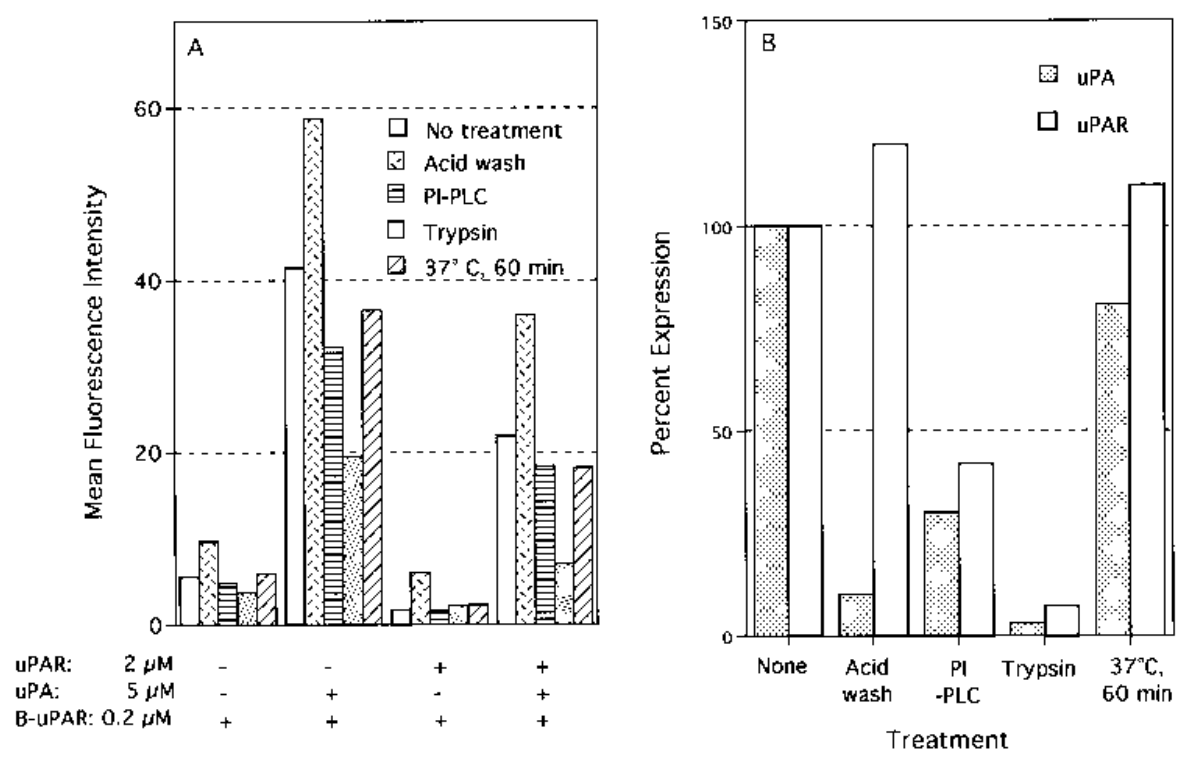

Fig. 5. Effect of treatment of PMAdifferentiated TH P-1 cells with acid washing, PI-PLC, or trypsin on the binding of $B$-suPAR in the presence or absence of exogenous UPA. PMA-differentiated TH P-1 cells were either untreated, acid washed, incubated in buffer alone for $60 \mathrm{~min}$ at $37^{\circ} \mathrm{C}$, incubated in buffer containing $\mathrm{PI}$ $\mathrm{PLC} 0.5 \mathrm{IU} / \mathrm{mL}$ for $60 \mathrm{~min}$ at $37^{\circ} \mathrm{C}$, or incubated in buffer containing trypsin $0.25 \%$ for $30 \mathrm{~min}$ at $37^{\circ} \mathrm{C}$. A fter washing, the cells were preincubated for $60 \mathrm{~min}$ at $25^{\circ} \mathrm{C}$ with $2 \mu \mathrm{M}$ unbiotinylated suPAR or buffer alone and then, without washing, incubated for $60 \mathrm{~min}$ at $25^{\circ} \mathrm{C}$ with either $0.2 \mu \mathrm{M} \mathrm{B}$-suPAR alone or a mixture of 0.2 $\mu \mathrm{M}$ B-suPAR + $5 \mu \mathrm{M}$ UPA. After washing and incubation with SA-PE for $30 \mathrm{~min}$ at $25^{\circ} \mathrm{C}$, cells were analyzed for bound $B$-suPA $R$ as indicated by their mean fluorescence intensity (arbitrary units) (A). Similar results were seen in two other experiments. A liquots of treated cells were subjected to indirect immunofluorescence analysis to determine the level of expression of membrane-associated UPA R and UPA (B). The level of expression of uPAR and uPA as seen in untreated cells was set at $100 \%$ (B) so as to compare the relative amounts of these surface proteins after treatment with acid washing, PI-PLC, trypsin, or incubation for 60 min at $37^{\circ} \mathrm{C}$.

binding (68 and $52 \%$ inhibition, $\mathrm{n}=2$ experiments, in the absence and presence of exogenous UPA, respectively).

H aving observed trypsin-sensitive specific binding of suPA R to THP-1 cells and purified human PMNs, we assayed other hematopoietic cells for the presence of B-suPA R binding sites. Among five additional human leukemic cell lines tested (including those that express or fail to express membraneassociated UPAR), all displayed the capacity to bind B-suPA R in a specific fashion (Fig. 6). There was no clear relationship between the expression or relative density of membraneassociated UPAR with the amount of B-suPAR bound. When buffy coat (unpurified) peripheral blood leukocytes were examined for B-suPAR binding (with or without pre-stimulation with $f M L P$, and with and without co-incubation with exogenous UPA), specific binding was observed for both PMNs and monocytes but not to lymphoid cells (Fig. 7). The presence of exogenous uPA enhanced B-suPA R binding to monocytes (similar to that seen with TH P-1 monocytic leukemia cells) but inhibited binding to PMNs (as seen with density gradient isolated PMNs). Prestimulation of buffy coat cells with fMLP had no consistent impact on the magnitude of $B$-suPA $R$ binding.

With the goal of positively identifying putative B-suPAR binding sites in THP-1 cells and PM Ns, we examined the effect of several monoclonal antibodies along with other reagents that might influence B-suPA R binding to specific membrane receptor sites. A mong the reagents examined were complex sugars [ $\alpha$-methyl-D-mannopyranside, $\mathrm{N}$-acetyl-D-glucosamine (NADG), and zymosan], which inhibit the physical linkage between membrane UPAR and members of the $\beta_{1}, \beta_{2}$, and $\beta_{3}$ integrins $[18,21,40]$; the calcium chelators EDTA and EGTA; murine $\mathrm{mAb}$ specific for CD11a, CD11b, CD11c, CD18, and UPAR (CD87); and polyclonal antibodies specific for the extracellular matrix proteins vitronectin, fibronectin, and thrombospondin. The effect of these agents on B-suPAR binding to PMAdifferentiated THP-1 cells and to unstimulated PMNs is shown in Figure 8, along with the surface expression of the proteins specified by the antibodies tested. Based on the combined results of multiple experiments performed, none of these agents produced a statistically significant inhibition of B-suPAR binding to either cell type. In data not shown, the enhanced binding of B-suPAR to THP-1 cells in the presence of exogenous UPA was also unaffected. The apparent enhancement of B-suPAR binding to PMNs caused by polyclonal anti-vitronectin and anti-thrombospondin antibodies (as shown in Fig. 8) did not reach statistical significance $(0.6<P<0.7)$. suPA $R$ binding to cells that express or lack membrane UPA $R$ (THP-1 and KG-1a cells, respectively) had no impact on the expression of cell-associated plasmin-mediated proteolysis when exogenous sources of UPA and plasminogen were added (data not shown). However, as shown in Fig. 9, suPAR pre-incubation was able to diminish the capacity of subsaturating amounts of exogenous uPA to bind to membraneassociated UPAR and catalyze the conversion of plasminogen to proteolytically active plasmin.

\section{DISCUSSION}

In this report we have demonstrated that recombinant suPAR can bind specifically to human hematopoietic cells that include normal peripheral blood PMNs and monocytes as well as a variety of myeloid leukemic cell lines. A mong the latter, as represented by THP-1 cells, binding was markedly enhanced by prior exposure to the differentiating agent PMA and by the co-exposure to exogenous UPA ligand. suPAR binding to monocytes was also increased by uPA but, as in the case with PMNs, was not affected by brief pre-exposure to soluble activating agents such as fML $P$ (under conditions that increase the surface expression of the $\beta_{2}$ integrins and certain other receptor proteins). Whereas exogenous UPA enhanced suPAR binding to these monocytic cells, depletion of endogenously bound UPA by acid washing was associated with an increase in suPA R binding that was further enhanced by the addition of 

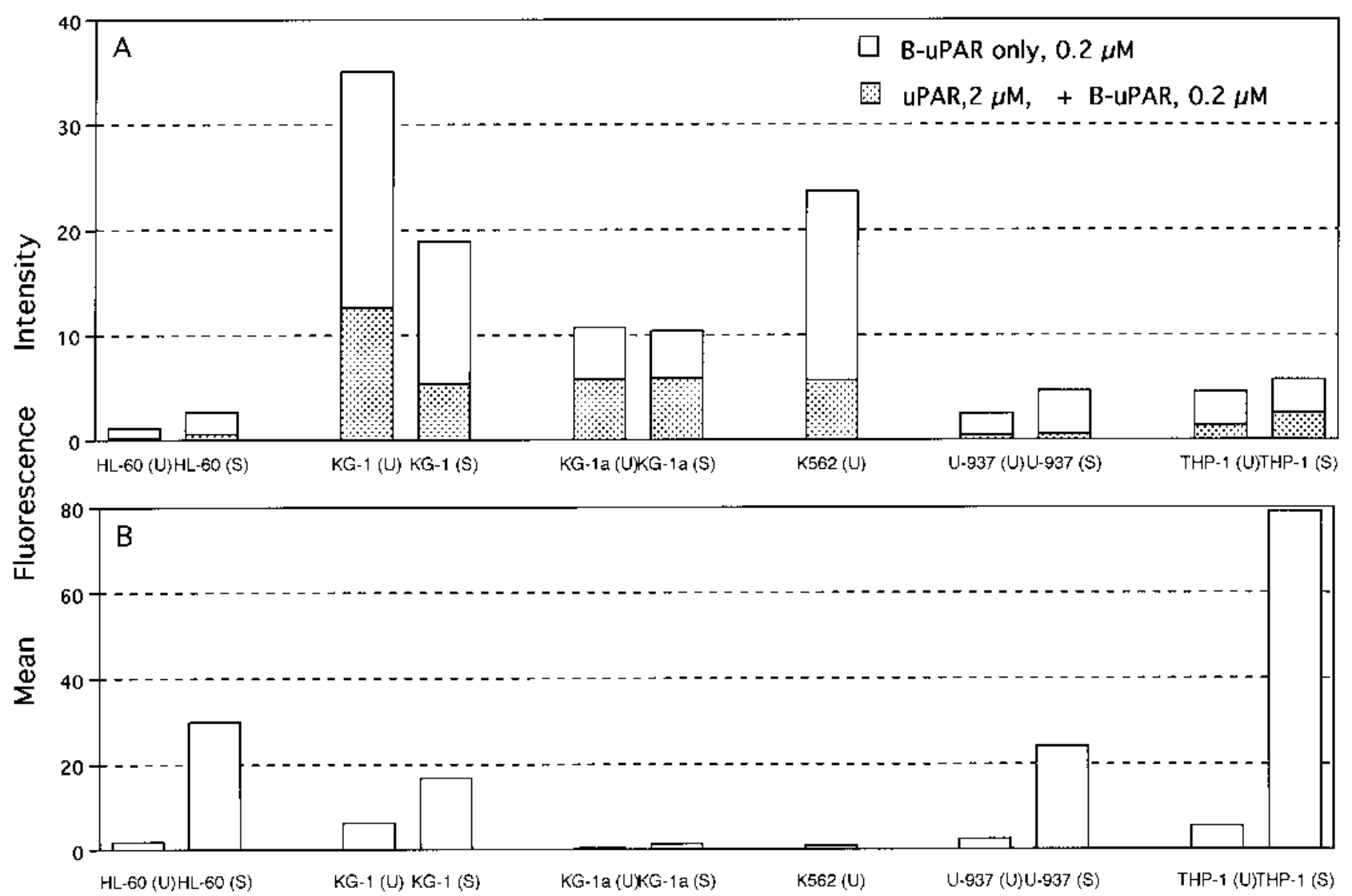

Myeloid Cell Lines

Fig. 6. Binding of B-suPAR to a panel of human myeloid leukemia cell lines that express or fail to express membrane-anchored uPAR. The indicated cell lines were

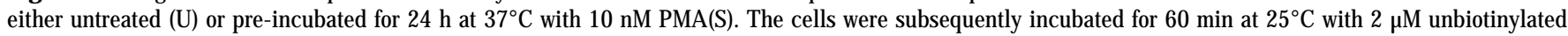
suPA R or buffer alone, and then, without washing, incubated for $60 \mathrm{~min}$ at $25^{\circ} \mathrm{C}$ with $0.2 \mu \mathrm{M} \mathrm{B}$-suPA R. A fter washing and incubation with $\mathrm{SA}-\mathrm{PE}$ for $30 \mathrm{~min}$ at $25^{\circ} \mathrm{C}$, cells were analyzed for bound B-suPA R as indicated by their mean fluorescence intensity (arbitrary units) (A). The stippled portion of each bar represents nonspecific $B$-suPAR binding, whereas the open portion represents specific binding. Similar results were seen in two other experiments. (B) The relative level of membrane-associated uPA R expressed by these cells as determined by indirect immunofluorescence analysis.

Fig. 7. Binding of B-suPAR with or without uPA to buffy coat lymphocytes, monocytes, and PMNs. Buffy coat leukocytes were either untreated or pre-incubated for 10 min at $37^{\circ} \mathrm{C}$ with $1 \mu \mathrm{M} \mathrm{fMLP}$. The cells were subsequently pre-incubated for $60 \mathrm{~min}$ at $25^{\circ} \mathrm{C}$ with $5 \mu \mathrm{M}$ unbiotinylated sUPAR or buffer alone, and then, without washing, incubated for $60 \mathrm{~min}$ at $25^{\circ} \mathrm{C}$ with $0.5 \mu \mathrm{M} \mathrm{B}$-suPAR alone or a mixture of $0.5 \mu \mathrm{M}$ B-suPAR $+5 \mu \mathrm{M}$ uPA. After washing and incubation with SA-PE for $30 \mathrm{~min}$ at $25^{\circ} \mathrm{C}$, cells were analyzed for bound B-suPAR as indicated by their mean fluorescence intensity (arbitrary units). Similar results were seen in three other experiments.

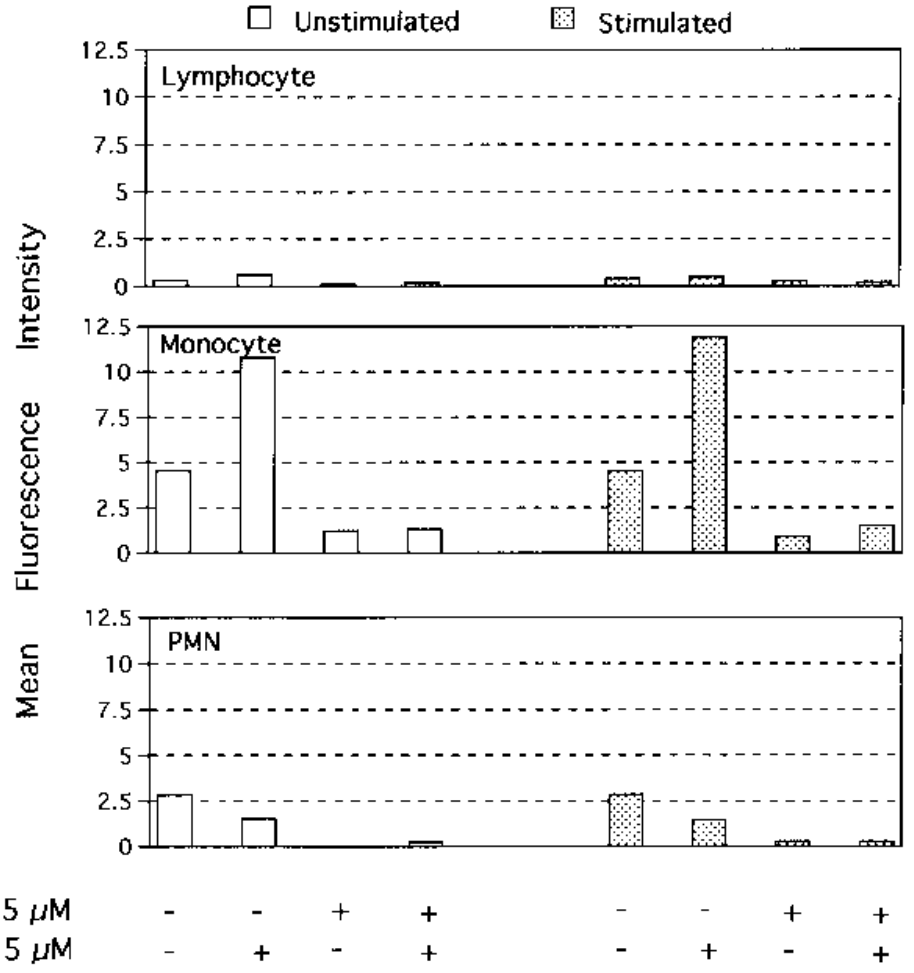

Mizukami and Todd Soluble urokinase receptor binding 209 
A

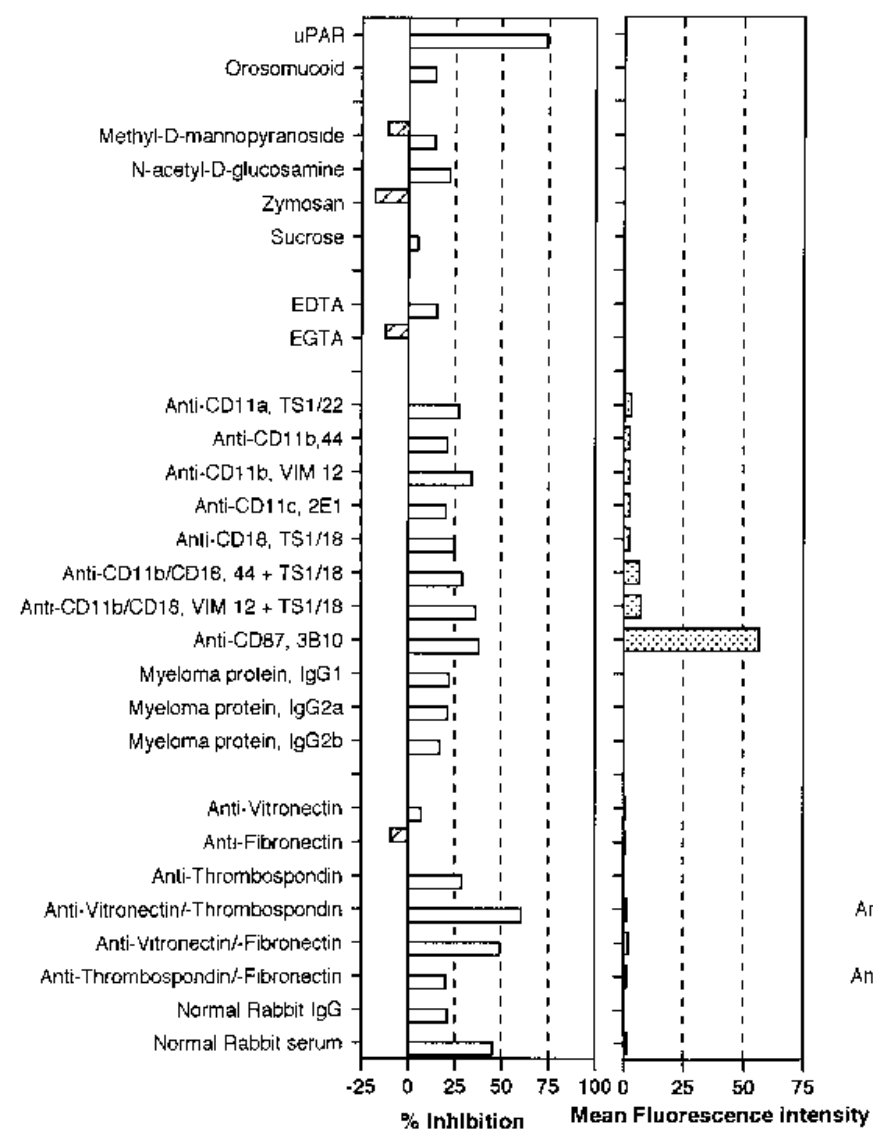

B

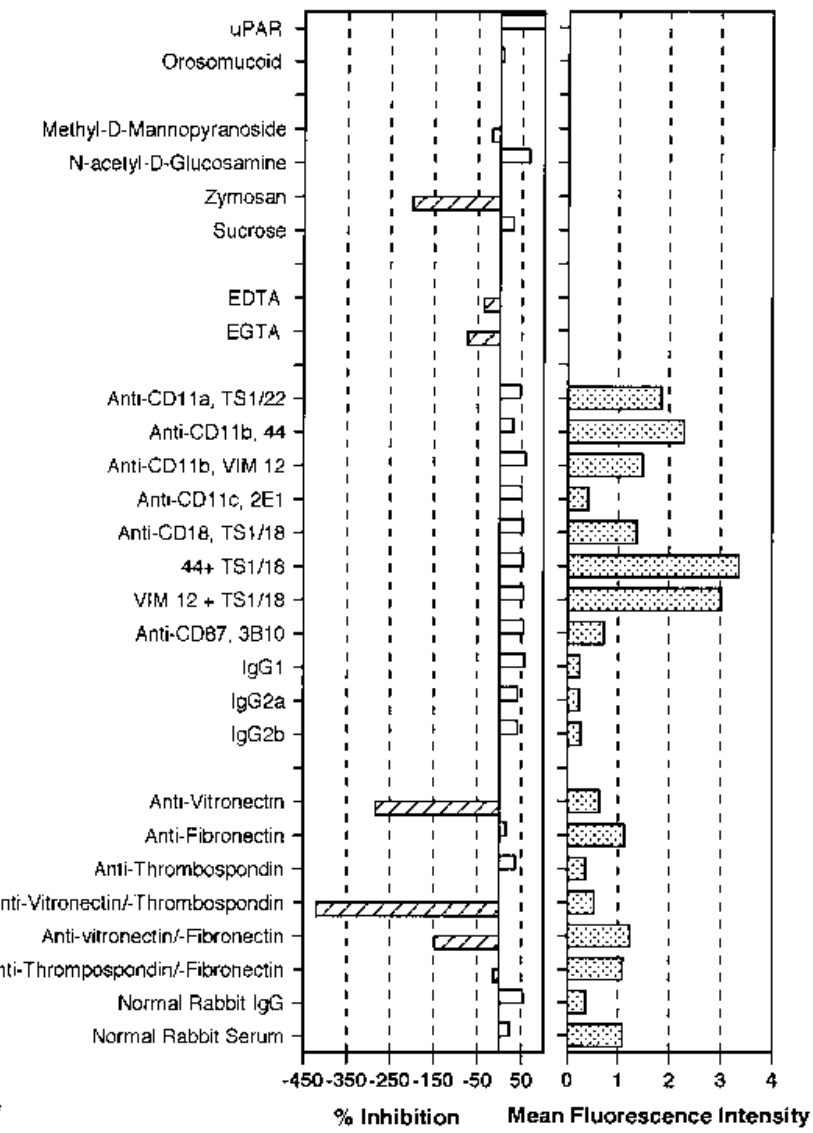

Fig. 8. E ffect of sugars, calcium chelators, and anti-integrin or anti-extracellular matrix protein antibodies on the binding of $B$-suPA R to TH P-1 cells and to isolated peripheral blood PMNs. PMA-differentiated TH P-1 cells (A) and unstimulated peripheral blood PM Ns (B) were pre-incubated for 60 min at $25^{\circ} \mathrm{C}$ with the indicated reagents. Then, without washing, the cells were incubated for $60 \mathrm{~min}$ at $25^{\circ} \mathrm{C}$ with B-suPA R $(0.2 \mu \mathrm{M}$ for TH P-1 cells; $0.5 \mu \mathrm{M}$ for PM Ns). A fter washing and incubation with SA-PE for $30 \mathrm{~min}$ at $25^{\circ} \mathrm{C}$, the cells were analyzed for bound B-suPA R as indicated by their mean fluorescence intensity (arbitrary units). The percent inhibition or enhancement of B-suPA R binding was calculated relative to the amount bound to untreated cells. For those cells pretreated with antibody reagents, aliquots were washed and stained with FITC-conjugated goat anti-mouse or anti-rabbit IgG to determine the relative amounts of each cell surface protein expressed by the cells (as shown by their mean fluorescence intensity (arbitrary units).

exogenous UPA. These observations tend to rule out the possibility that suPAR simply binds to endogenous UPA bound to membrane-associated UPAR, but may instead bind to receptor sites that have a higher affinity for UPAR-UPA complexes. This supports the conclusions made by Higazi et al. [45] (and corroborated by Chavakis et al. [46]), who demonstrated that suPAR complexed with UPA binds specifically to the LM-TK - fibroblast cell line (genetically deficient in GPI proteins), leading them to propose that UPA associated with SUPAR induces the appearance of unique binding epitopes recognized by cell surface receptors. However, unlike the results of $\mathrm{Higazi}$ et al., in which binding of suPAR alone to fibroblasts was negligible, specific suPAR binding to THP-1 cells and monocytes was not dependent on the development of a molecular complex with UPA. A lack of uPA dependence was even more apparent in PMNs in which co-incubation with exogenous UPA inhibited the binding of suPAR. Clearly, the binding characteristics of suPAR receptor sites on PMAdifferentiated THP-1 cells differ from those expressed by PMNs.

Having demonstrated the existence of suPA $R$ binding sites on a variety of human hematopoietic cells, we performed a series of experiments designed to better characterize them. Treatment of THP-1 cells with PI-PLC under conditions that partially depleted the plasma membrane of UPAR had no significant effect on SUPAR binding, tending to exclude the possibility that suPAR forms a complex with its membrane counterpart. This conclusion is further supported by the high degree of suPAR binding to KG-1a and K562 cells, which do not express membrane-anchored UPAR. suPAR binding was diminished by pretreatment of THP-1 cells with trypsin, consistent with the premise that SUPAR receptor sites are cell surface proteins. We strongly considered the possibility that members of the $\beta_{2}$ integrin family, Mo1 (CD11b/CD18) and/or p150, 95 (CD11C/CD 18) serve as suPAR binding sites. We and others have shown that in PMNs and monocytes, membraneanchored UPA R can form reversible non-coval ent linkages with these two integrins $[15,18,20,22]$ depending on the state of cellular polarity $[19,20]$ : UPAR co-associates with Mol in resting non-polarized cells but links up with p150, 95 at the lamellipodia of polarized migrating cells [20]. These physical linkages, as detected by receptor co-capping and resonance energy transfer experiments, are inhibitable by certain complex sugars [18] (including $\alpha$-methyl-D-mannopyranoside and 


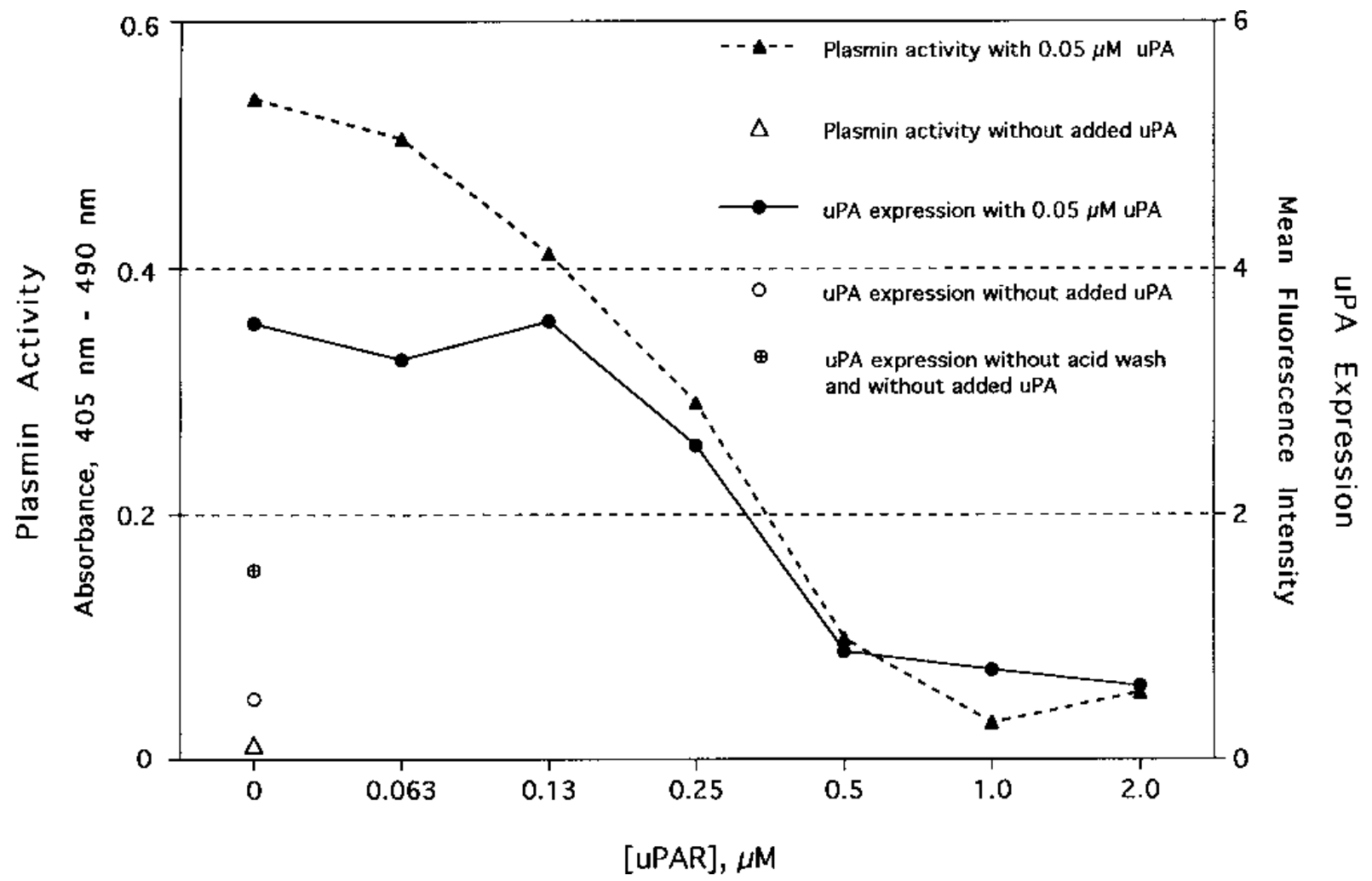

Fig. 9. Effect of suPAR on binding and plasminogen activating capacity of exogenous uPA. PMA-differentiated THP-1 cells were acid-washed to remove endogenously bound UPA and incubated for $60 \mathrm{~min}$ at $25^{\circ} \mathrm{C}$ with $0.05 \mu \mathrm{M} \mathrm{HMW}$ uPA that had been pre-incubated $\left(10\right.$ min at $\left.25^{\circ} \mathrm{C}\right)$ with the indicated quantities of suPAR. Aliquots of these cells were washed and (1) assayed for the quantity of uPA bound as measured by indirect immunofluorescence (filled circles) or (2) incubated for $120 \mathrm{~min}$ at $37^{\circ} \mathrm{C}$ with plasminogen and Spectrozyme PL to detect cell-associated plasmin activity as measured by a microplate reader (absorbance at 405- $490 \mathrm{~nm}$; filled triangles). Identical results were seen in one other experiment.

NADG), leading us to propose that lectin sites on Mol and possibly p150, 95 provide the structural basis for binding to UPAR-associated carbohydrate, thereby resulting in interreceptor linkage. With this notion in mind, we tested the capacity of NADG, $\alpha$-methyl-mannopyranoside, and a variety of $m A$ bs specific for the $\beta_{2}$ integrins to competitively inhibit the binding of suPAR to PMA-differentiated THP-1 cells and to unstimulated PMNs. As a precedent for these experiments were the findings of $\mathrm{Gal}$ on et al. [35], who reported that the specific binding of biotinylated soluble CD16b (FCyRIIIb) to Mol and p150, 95 expressed by a variety of human myeloid cells (supporting the results of our earlier co-capping results that predicted such a linkage [47]). Surprisingly, we observed no statistically significant inhibition by the sugars or anti-integrin antibodies. A variable degree of inhibition was observed when THP-1 cells and PMNs were pretreated with anti-CD11b mAb VIM 12, which recognizes an epitope in the lectin domain of Mol [40] (and which inhibits the binding of SCD16b to Mol [35]). H owever, inhibition produced by VIM 12 did not reach statistical significance compared with isotype-identical negative control antibodies.

We then explored the possibility that suPA R in the presence or absence of uPA recognizes membrane-bound vitronectin and thrombospondin as reported by Higazi et al. [45], who found that a combination of antibodies specific for these proteins completely inhibited the binding of the suPA R/uPA complex to LM-TK - fibroblasts. The binding of a complex of suPAR/UPA to vitronectin associated with vascular endothelial cells was also reported by Chavakis et al. [46]. However, polyclonal antibodies specific for vitronectin and thrombospondin (alone or in combination) failed to cause a decrement in suPAR binding (alone or in combination with UPA); indeed, a trend (not statistically significant) toward enhancement of suPAR binding was observed in PMNs pretreated with these antibodies.

On the basis of our results to date, we can make no firm conclusions about the nature of the cellular binding sites for sUPAR. We cannot as yet exclude the possibility that suPAR recognizes members of the $\beta_{2}$ integrin family inasmuch as pretreatment with the panel of $\mathrm{mA} b$ tested may not be sufficient to block relevant binding domains expressed by these proteins, and their affinity for each other may be weak (as suggested by the reversibility of UPAR's linkage with both Mo1 and p150,95 $[19,20])$. We will explore the possible role of $\beta_{2}$ integrins as receptors for sUPA $R$ in subsequent binding studies involving PMNs from patients with leukocyte adhesion deficiency (who lack expression of the $\beta_{2}$ integrins) and transfectant cell lines expressing various members of the $\beta_{2}$ integrin family.

With respect to the function of suPAR, we previously reported that exposure of human peripheral blood monocytes rendered membrane UPAR-negative (by pretreatment with UPA R antisense oligonucleotides) to recombinant suPAR could restore the ability of these cells to bind to fibrinogen in a M ol-dependent fashion [14]. That is, suPA R could reconstitute a function normally subserved by the membrane-anchored form 
of the protein. Conversely, other investigators have found that suPA R could inhibit uPA-dependent cellular effector responses (e.g., proliferation and invasion of tumor cells [31, 32]), suggesting that sUPAR competes with membrane UPAR to down-regulate uPA-dependent signaling events. In experiments reported here, we have confirmed suPA R's capacity to scavenge UPA as reflected by diminished cell-associated plasminogen activation. Conversely, we found no evidence that suPAR binding could enhance plasminogen activation by membrane UPAR-negative cell lines. Therefore, at present we conclude that suPA $R$ can bind in a specific fashion to a variety of human hematopoietic cells where its binding is variably influenced by the differentiation state of the cell and the presence of exogenous UPA ligand. The precise nature of the binding sites for UPAR is unresolved but, based on prior co-capping experiments, might include members of the $\beta_{2}$ integrin family of glycoproteins to which UPA R is functionally linked.

\section{ACKNOWLEDGMENTS}

The authors wish to thank Mr. Mark KuKuruga and Ms. Ann Marie DesLauriers for their help with flow cytometric analysis; Drs. R ichard H art (A merican Diagnostica), Martin Low (Columbia University), Timothy Springer (Harvard University), and Robert Cohen (Genentech) for gifts of reagents invaluable to the pursuit of this study. This work was supported by NIH Grants CA39064, CA 42246, AR 20557, and CA 46592.

\section{REFERENCES}

1. Dano, K., Behrendt, N., Brenner, N., Ellis, V., Ploug, M., Pyke, C. (1994) The urokinase receptor. Protein structure and role in plasminogen activation and cancer invasion. Fibrinolysis 8, 189-203.

2. Blasi, F. (1993) Urokinase and urokinase receptor: A paracrine/autocrine sytem for regulating cell migration and invasiveness. Bioessays 15, 105-111.

3. Todd, R. F., III, Alvarez, P. A., Brott, D. A., Liu, D. Y. (1985) Bacterial lipopolysaccharide, phorbol myristate acetate, and muramyl dipeptide stimulate the expression of a human monocyte surface antigen, Mo3e. J. Immunol. 135, 3869-3877.

4. Nykjaer, A., Moller, B., Todd, R. F., III, Christensen, T., Andreasen, P. A., Gliemann, J., Petersen, C. M. (1994) U rokinase receptor: An activation antigen in human T lymphocytes. J. Immunol. 152, 505-516.

5. Picone, R., Kajtaniak, E. L., Nielsen, L.. S., Behrendt, N., Mastronicola, M. R., Cubellis, M. V., Stoppelli, M. P., Pedresn, S., Dano, K., Blasi, F. (1989) Regulation of urokinase receptors in monocyte-like U-937 cells by phorbol ester myristate acetate. J. Cell. Biol. 108, 693-702.

6. Lund, L. R., Ronne, E., Roldan, A. L., Behrendt, N., Romer, J., Blasi, F., Dano, K. (1991) Urokinase receptor mRNA level and gene transcription are strong and rapidly increased by phorbol myristate acetate in human monocyte-like U-937 cells. J. Biol. Chem. 266, 5177-5181.

7. Plesner, T., Ploug, M., Ellis, V., R onne, E., H oyer-H ansen, G., Wittrup, M., Pedersen, T. L., Tscherning, T., Dano, K., Hansen, N. E. (1994) The receptor for urokinase-type plasminogen activator and urokinase is translocated from two distinct intracellular compartments to the plasma membrane on stimulated human neutrophils. Blood 83, 808-815.

8. Nusrat, A. R., Chapman, H. A. (1991) An autocrine role for urokinase in phorbol ester-mediated differentiation of myeloid cells. J . Clin. Invest. 87, 1091-1097.

9. Kircheimer, J. C., Wojta, J., Christ, G., Binder, B. R. (1989) The functional inhibition of endogenously produced urokinase decreases cell proliferation in a human melanoma cell line. Proc. Natl. Acad. Sci. USA 86, 5424-5428.

10. Wei, Y., Waltz, D. A., R ao, N., Drummond, R. J ., R osenberg, S., Chapman, H. A. (1994) Identification of the urokinase receptor as an adhesion receptor for vitronectin. J. Biol. Chem. 269, 32380-32388.
11. Cao, D., Mizukami, I. F., Garni-Wagner, B. A., Todd, R. F., III, Boxer, L. A., Petty, H. R. (1995) Human urokinase-type plasminogen activator primes neutrophils for superoxide anion release: possible roles of complement receptor type III and calcium. J . Immunol. 154, 1817-1829.

12. Gyetko, M. R., Todd, R. F., III, Wilkinson, C. C., Sitrin, R. G. (1994) The urokinase receptor is required for human monocyte chemotaxis in vitro. J. Clin. Invest. 93, 1380-1387.

13. Gyetko, M. R., Sitrin, R. G., Fuller, J. A., Todd, R. F., III, Petty, H. R., Standiford, T. J. (1995) Function of the urokinase receptor (CD87) in neutrophil chemotaxis. J. Leukoc. Biol. 58, 533-538.

14. Sitrin, R. G., Todd, R. F., III, Petty, H. R., Brock, T. G., Shollenberger, S. B., Gyetko, M. R. (1996) The urokinase receptor (CD87) facilitates CD11b/CD 18-mediated adhesion of human monocytes. J. Clin. Invest. 97, 1942-1951.

15. Wei, Y., Lukashev, M., Simon, D. I., Bodary, S. C., Rosenberg, S., Doyle, M. V., Chapman, H. A. (1996) R egulation of integrin function by urokinase receptor. Science 273, 1551-1555.

16. Petty, H. R., Kindzelskii, A. L., Adachi, Y., Todd, R. F., III (1997) Ectodomain interactions of leukocyte integrins and proinflammatory GPI-linked membrane proteins. J. P harmaceut. Biomed. Anal. 15, 14051416.

17. Todd, R. F., III, Petty, H. R. (1997) $\beta 2$ (CD11/CD 18) integrins can serve as signaling partners for other leukocyte receptors. J. Lab. Clin. Med. 129, 492-498.

18. Xue, W., Kindzelskii, A. L., Todd, R. F., III, Petty, H. R. (1994) Physical association of complement receptor type 3 and urokinase-type plasminogen activator receptor in neutrophil membranes. J. Immunol. 152, $4630-4640$.

19. Kindzelskii, A. L., Laska, Z. O., Todd, R. F., III, Petty, H. R. (1996) U rokinase-type plasminogen activator receptor reversibly dissociates from complement receptor type $3\left(\alpha_{m} \beta_{2}, C D 11 b / C D 18\right)$ during neutrophil polarization. J . Immunol. 156, 297-309.

20. Kindzelskii, A. L., Eszes, M. M., Todd, R. F., III, Petty, H. R. (1997) Proximity oscillations of complement type $4\left(\alpha_{x} \beta_{2}\right)$ and urokinase receptors on migrating neutrophils are linked with signaling/metabolic oscillations. Biophys. J. 73, 1777-1784.

21. Xue, W., Mizukami, I. F., Todd, R. F., III, Petty, H. R. (1997) Colocalization of UPAR with $\beta 1$ and $\beta 3$ integrins on tumor cells adherent to specific extracellular matrices. Cancer Res. 57, 1682-1689.

22. Bohuslav, J., H orejsi, V., Hansmann, C., Stockl, J., Weidle, U. H., Majdic, O., Bartke, I., Knapp, W., Stockinger, H. (1995) U rokinase plasminogen activator receptor, $\beta 2$-integrins and Src-kinases within a single receptor complex of human monocytes. J. Exp. Med. 181, 1381-1390.

23. Simon, D. I., Rao, N. K., Xu, H., Wei, Y., Majdic, O., Ronne, E., Kobzik, L., Chapman, H. A. (1996) Mac-1 (CD11b/CD 18) and the urokinase receptor (CD87) form a functional unit on monocytic cells. Blood 88, 3185-3194.

24. Bazil, V. (1995) Physiologic enzymatic cleavage of leukocyte membrane molecules. Immunol. Today 16, 135-140.

25. Sitrin, R. G., Todd, R. F., III, Mizukami, I. F., Gross, T. J., Shollenberger, S. B., Gyetko, M. R. (1994) Cytokine-specific regulation of urokinase receptor (CD87) expression by U937 mononuclear phagocytes. Blood 84, 1268-1275.

26. Mizukami, I. F., Faulkner, N. E., Gyetko, M. R., Sitrin, R. G., Todd, R. F., III. (1995) ELISA detection of a soluble form of urokinase plasminogen activator receptor (suPA-R) in vivo. Blood 86, 203-211.

27. Ronne, E., Pappot, H., Grondahl-H ansen, J., H oyer-H ansen, G., Plesner, T., H ansen, N. E., Dano, K. (1995) The receptor for urokinase plasminogen activator is present in plasma from normal donors and elevated in patients with paroxysmal nocturnal haemoglobinuria. Br. J. Haematol. 89, 576581.

28. Pappot, H., Hoyer-Hansen, G., R onne, E., Hansen, H. H., Brunner, N., Dano, K., Grondahl-H ansen, J. (1997) Elevated plasma levels of urokinase plasminogen activator receptor in non-small cell lung cancer patients. Eur. J. Cancer 33, 867-872.

29. Ploug, M., Eriksen, J., Plesner, T., Hansen, N. E., Dano, K. (1992) A soluble form of glycolipid-anchored receptor for urokinase-type plasminogen activators secreted from peripheral blood leukocytes from patients with paroxysmal noctural hemoglobinuria. Eur. J. Biochem. 28, 397-404.

30. Pedersen, N., Schmitt, M., R onne, E., Nicolettim, M. I., H oyer-H ansen, G., Conese, M., Giavazzi, R., Dano, K., K uhn, W., Janicke, F., Blasi, F. (1993) A ligand-free, soluble urokinase receptor is present in the ascitic fluid from patients with ovarian cancer. J. Clin. Invest. 92, 2160-2167.

31. Wilhelm, O., Weidle, U., H ohl, S., R ettenberger, P., Schmitt, M., Graeff, H. (1994) Recombinant soluble urokinase receptor as a scavenger for urokinase-type plasminogen activator (UPA). FEBS Lett. 337, 131-134.

32. Masucci, M. T., Pedersen, N., Blasi, F. (1991) A soluble, ligand binding mutant of the human urokinase plasminogen activator receptor. J. Biol. Chem. 266, 8655-8658. 
33. Nykjaer, A., Kjoller, L., Cohen, R. L., Lawrence, D. A., Garni-Wagner, B. A., Todd, R. F., III, Van Zonneveld, A-J., Gliemann, J., Andreasen, P. A. (1994) Regions involved in binding of urokinase: type-1 inhibitor complex and pro-urokinase to the endocytic $\alpha 2$-macroglobulin receptor/LDL receptor related protein. J. Biol. Chem. 269, 25668-25676.

34. Vita, N., Lefort, S., Sozzani, P., R eeb, R., Richards, S., Borysiewicz, L. K., Ferrara, P., Labeta, M. O. (1997) Detection and biochemical characteristics of the receptor for complexes of soluble CD14 and bacterial lipopolysaccharide. J. Immunol. 158, 3457-3462.

35. Galon, J., Gauchat, J-F., Mazieres, N., Spagnoli, R., Storkus, W., Lotz, M., Bonnefoy, J-Y., Fridman, W-H., Sautes, C. (1996) Soluble Fcy receptor type III ( $F(\gamma R$ III, CD 16) trigger cell activation through interaction with complement receptors. J. Immunol. 157, 1184-1192.

36. Sanchez-Madrid, F., Nagy, J., Robbins, E., Simon, P., Springer, T. (1983) A human leukocyte differentiation antigen family with distinct $\alpha$ subunits and a common $\beta$ subunit: The lymphocyte function-associated antigen (LFA-1), the C 3 bi complement receptor (OKM-1/Mac-1), and the p150, 95 molecule. J. Exp. Med. 158, 1785-1803.

37. Dana, N., Styrt, B., Griffin, J., Todd, R., III, Klempner, M., Arnaout, M. (1986) Two functional domains in the phagocyte membrane glycoprotein Mol identified with monoclonal antibodies. J. I mmunol. 137, 3259-3263.

38. Mizukami, I. F., Vinjamuri, S. D., Trochelman, R. D., Todd, R. F., III (1990) A structural characterization of the Mo3 activation antigen expressed on the plasma membrane of human mononuclear phagocytes. J. Immunol. 144, 1841-1848.

39. Luck, J., Luther, E., Diamond, M. S., Springer, T. A. (1995) Subunit specificity in epitope mapping of Mac-1 and p150, $95 \mathrm{mAb}$ using chimeric CD11b + CD11c transfectants. In Leukocyte Typing V, Oxford, UK : Oxford University Press, 1599-1601.

40. Stockl, J., Majdic, O., Pickl, W. F., R osenkranz, A., Prager, E., Gschwantler, E., Knapp, W. (1995) Granulocyte activation via a binding site near the C-terminal region of complement receptor type III $\alpha$-chain (CD11b) potentially involved in intramembrane complex formation with glycosylphosphatidylinositol-anchored F cyR IIIb (CD16) molecules. J. I mmunol. 154, 5452-5463.

41. Mizukami, I. F., Garni-Wagner, B. A., DeA ngelo, L. M., Libert, M., Flint, A., Lawrence, D. A., Cohen, R. O., Todd, R. F., III (1994) Immunologic protection of the cellular receptor for urokinase plasminogen activator. Clin. Immunol. Immunopathol. 71, 96-104.

42. Cole, R. C., A shman, L. K., Ey, P. L. (1987) Biotinylation: An alternative to radioiodination for the identification of cell surface antigens in immunoprecipitates. Mol. Immunol. 4, 699-705.

43. Levy, P. C., Shaw, G. M., LoBuglio, A. G. (1979) Human monocyte, lymphocyte, and granulocyte antibody-dependent cell-mediated cytotoxicity toward tumor cells. I. General characteristics of cytolosis. J. Immunol. 123, 594-599.

44. Schaefer, B. M., Maier, K., Eickhoff, U., Todd, R. F., III, Kramer, M. D. (1994) Plasminogen activation in healing human wounds. Am. J. Pathol. $144,1269-1280$.

45. Higazi, A. A., Upson, R. H., Cohen, R. L., Manuppello, J., Bognacki, J., Henkin, J., McCrae, K. R., K ounnas, M. Z., Strickland, D. K., Preissner, K. T., Lawler, J., Cines, D. B. (1996) Alteration of single-chain urokinase with its receptor induces the appearance and disappearance of binding epitopes within the resultant complex for other cell surface proteins. Blood 88, 542-551.

46. Chavakis, T., Kanse, S. M., Yutzy, B., Lijnen, H. R., Preissner, K. T. (1998) Vitronectin concentrates proteolytic activity on the cell surface and extracellular matrix by trapping soluble urokinase receptor-urokinase complexes. Blood 91, 2305-2312.

47. Zhou, M-J., Todd, R. F., III, van de Winkel, J. G. J., Petty, H. R. (1993) Co-capping of leukoadhesion molecules complement receptor type III and Iymphocyte function-associated antigen-1 with $\mathrm{F} c \gamma$ receptor III on human neutrophils. J. Immunol. 150, 3030-3041. 